Article

\title{
Crystal Structures of Furazanes
}

\author{
Thomas M. Klapötke *, Philipp C. Schmid ${ }^{\dagger}$ and Jörg Stierstorfer ${ }^{\dagger}$ \\ Department of Chemistry, Ludwig-Maximilian University of Munich, Butenandtstr. 5-13 (Haus D) \\ München D-81377, Germany; E-Mails: phisch@cup.uni-muenchen.de (P.C.S.); \\ jstch@cup.uni-muenchen.de (J.S.) \\ $\dagger$ These authors contributed equally to this work. \\ * Author to whom correspondence should be addressed; E-Mail: tmk@cup.uni-muenchen.de; \\ Tel.: +49-(0)89-2180-77491; Fax: +49-(0)89-2180-77492.
}

Academic Editor: Gerhard Laus

Received: 31 July 2015 / Accepted: 14 September 2015 / Published: 24 September 2015

\begin{abstract}
Several nitrogen-rich salts of 3-nitramino-4-nitrofurazane and dinitraminoazoxyfurazane were synthesized and characterized by various spectroscopic methods. The crystal structures were determined by low temperature single crystal X-ray diffraction. Moreover the sensitivities toward thermal and mechanical stimuli were determined by differential thermal analysis (DTA) and BAM (Bundesanstalt für Materialforschung und -prüfung) methods. The standard enthalpies of formation were calculated for all compounds at the CBS-4M level of theory, and the energetic performance was predicted with the EXPLO5 V6.02 computer code.
\end{abstract}

Keywords: X-ray; energetic; furazane; nitrogen-rich salts; nitramino

\section{Introduction}

Modern energetic materials need to fulfill several criteria to become potential replacements for commonly used Research Department explosive (RDX). In addition to having excellent detonation velocities and pressures, new secondary explosives must comply with certain safety criteria, such as a decomposition temperature over $200{ }^{\circ} \mathrm{C}$ and low sensitivity to mechanical stimuli as impact (>7.5 J) or friction $(>120 \mathrm{~N})$. In recent years, the growth in environmental concern has resulted in the desire for energetic materials that release environmentally benign dinitrogen after decomposition [1]. 
Forming the energetic salt of a neutral compound can improve the performance of explosives without compromising their safety [2]. We recently reported on the two nitrogen-rich cations 4,4',5,5'tetraamino-3,3'-bi-triazolium [3] and 3,6,7-triamino[1,2,4]triazolo[4,3-b][1,2,4]triazolium [4], which can form thermally stable energetic salts. With these two nitrogen-rich cations in hand, we have now synthesized several new ionic furazanes to increase the decomposition temperatures of previously known 3-nitramino-4-nitrofurazan 4 [5] and dinitraminoazoxyfurazan 10 [6]. Moreover, we report on the crystal structures of the 3-nitramino-4-nitrofurazan $\mathbf{4}$ as well as its hydroxylammonium $\mathbf{5}$ and ammonium $\mathbf{6}$ salt. Although compounds 4-6 have been previously described in the literature [5,7], X-ray analyses deliver insight into structural characteristics that could explain the high density of this interesting class of energetic molecules.

\section{Results and Discussion}

\subsection{Synthesis}

The preparations of the energetic derivatives of 3-nitramino-4-nitrofurazan 4 and dinitraminoazoxyfurazan $\mathbf{1 0}$ are displayed in Figure 1.

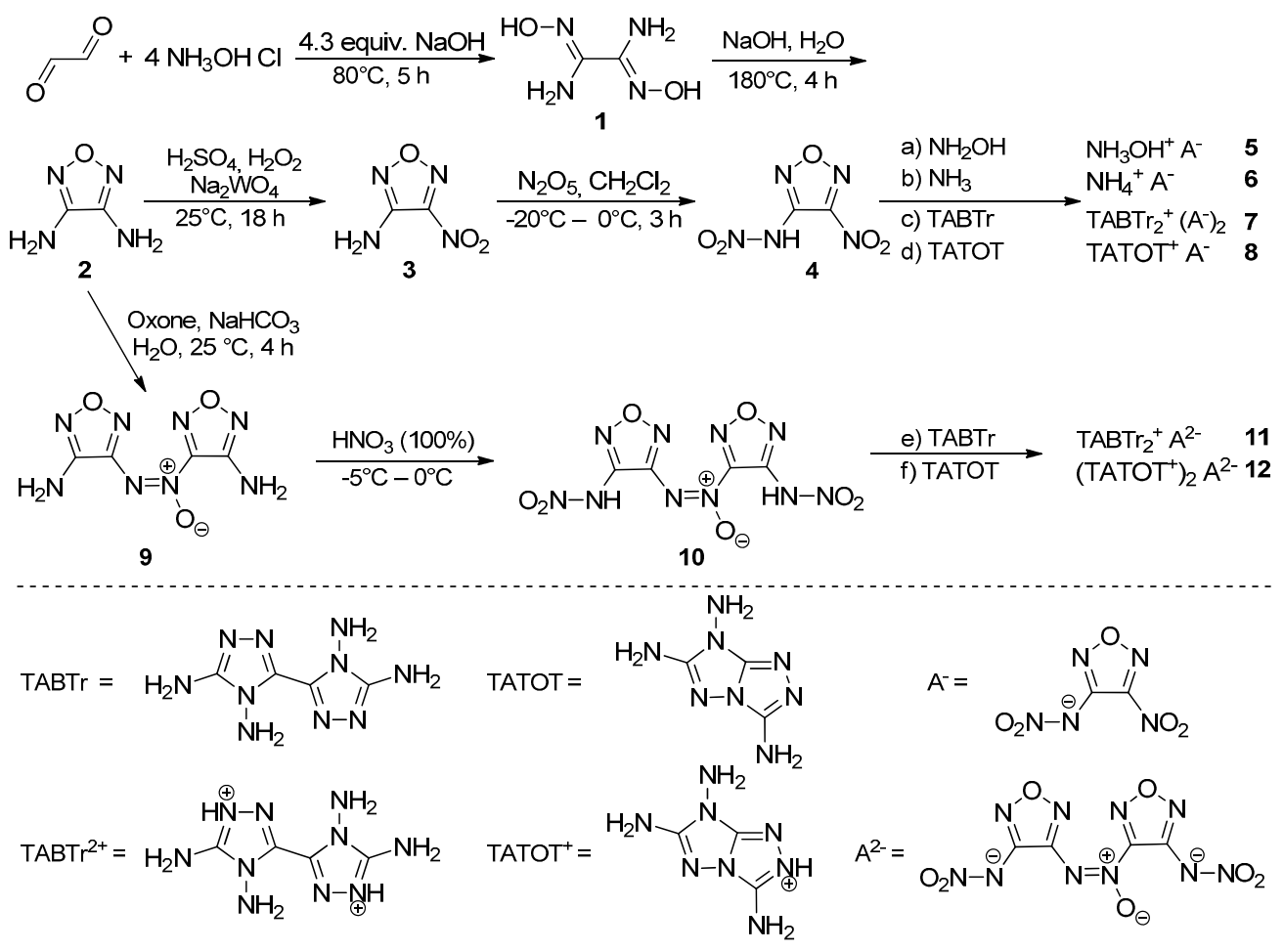

Figure 1. Synthesis of 3-nitramino-4-nitrofurazan $\mathbf{4}$ and dinitraminoazoxyfurazan $\mathbf{1 0}$ as well as their energetic salts.

Glyoxal was stirred with 4.3 equivalents of hydroxylammonium chloride under basic conditions to give diaminoglyoxime 1 [8]. Compound 1 was heated in an autoclave to build the furazan ring eliminating one molecule of water to give diaminofurazan $\mathbf{2}$ [8]. To obtain compound $\mathbf{3}$, compound $\mathbf{2}$ was oxidized with persulfuric acid and $\mathrm{Na}_{2} \mathrm{WO}_{4}$ [9]. Compound $\mathbf{3}$ can be easily nitrated under relatively "mild" conditions with $\mathrm{N}_{2} \mathrm{O}_{5}$ to give 3-nitramino-4-nitrofurazan 4 [5]. The energetic salts 
hydroxylammonium 3-nitramino-4-nitrofurazan 5, ammonium 3-nitramino-4-nitrofurazan (6), 4,4',5,5'tetraamino-3,3'-bi-triazolium di-3-nitramino-4-nitrofurazan 7 and 3,6,7-triamino-[1,2,4]triazolo [4,3-b][1,2,4]triazolium 3-nitramino-4-nitrofurazan 8 can be synthesized by treating compound 4 with the respective base.

Diaminofurazane 2 was treated with Oxone ${ }^{\circledR}$ and sodium bicarbonate as described by Chavez et. al. to give diaminoazoxyfurazan 9 [10]. Compound 9 was then stirred in nitric acid (100\%) to nitrate the two amino groups to obtain dinitraminoazoxyfurazan 10 [6]. Two thermally stable derivatives 4,4',5,5'tetraamino-3,3'-bi-triazolium dinitraminoazoxyfurazan 11 and di-3,6,7-triamino-[1,2,4]triazolo[4,3-b] $[1,2,4]$ triazolium dinitraminoazoxyfurazan $\mathbf{1 2}$ were obtained by treating the acid $\mathbf{1 0}$ with the corresponding bases.

\subsection{Crystal Structure}

The crystal structures of compounds 3-6, 8 and $\mathbf{1 2}$ were determined. Tables S1-S2 in the Supporting Information gather selected data and parameters of the X-ray measurements. Once crystals were obtained for each compound, we did not attempt to search for additional polymorphs of each.

The compound 3-Amino-4-nitraminofurazan 3 crystallizes in the orthorhombic space group Pna21 with a cell volume of $938.26 \AA^{3}$ and eight molecular units per unit cell (Figure 2 ). The calculated density at $173 \mathrm{~K}$ is $1.842 \mathrm{~g} \cdot \mathrm{cm}^{-3}$, which is similar to the previously reported density of $1.84 \mathrm{~g} \cdot \mathrm{cm}^{-3}$ (X-ray analysis at $153 \mathrm{~K}$ ) [11]. Compound 3 is planar, only the nitro moiety is slightly tilted against the furazan plane by a torsion angle of $\mathrm{O} 2-\mathrm{N} 3-\mathrm{C} 1-\mathrm{C} 2=4.4^{\circ}$. Short hydrogen bonding can be observed between the amino and nitro groups, similar bond distances have been reported for other furazanes in the literature [6]. A more detailed description of the structure can be found in the literature [11].

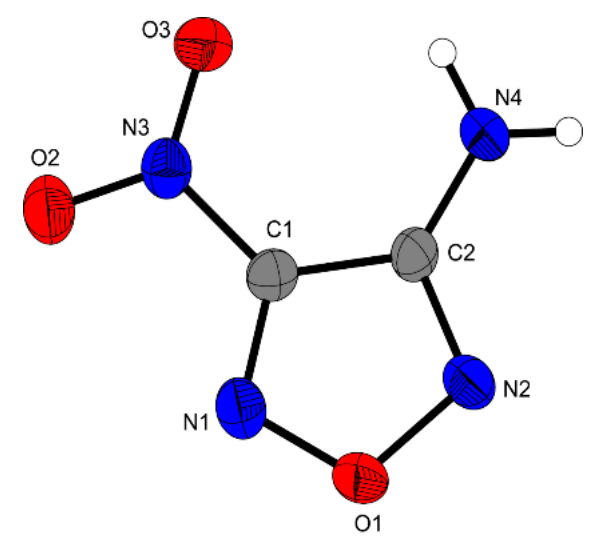

Figure 2. Molecular unit of 3. Ellipsoids are drawn at the $50 \%$ probability level. Selected bond distances $(\AA)$ : O1-N1 1.352(4), O1-N2 1.409(5), C1-C2 1.428(6), N4-N2 1.331(7), $\mathrm{N} 3-\mathrm{C} 1$ 1.450(5), O2-N3 1.226(5); selected bond angles $\left(^{\circ}\right)$ : N1-O1-N2 111.1(3), N1-C1-C2 111.8(3), N3-C1-C2 128.1(4), N4-C2-C1 129.5(4); selected hydrogen bond distances $[\AA]$ and angles $\left[^{\circ}\right](\mathrm{D}-\mathrm{H} \ldots \mathrm{A}, \mathrm{d}(\mathrm{D}-\mathrm{H}), \mathrm{d}(\mathrm{H} \cdots \mathrm{A}), \mathrm{d}(\mathrm{D} \ldots \mathrm{A}),(\mathrm{D}-\mathrm{H} \ldots \mathrm{A})$ ): N4-H4A...O3: 0.87(5), 2.38(5), 2.919(5), 120(4); N4-H4A...N1 0.87(5), 2.29(2), 3.084(6), 152(5); selected torsion angles $\left({ }^{\circ}\right)$ : $\mathrm{N} 2-\mathrm{O} 1-\mathrm{N} 1-\mathrm{C} 1$ 0.6(4), O2-N3-C1-C2 4.4(5), O1-N2-C2-N4 179.2(4). 
The compound 3-Nitramino-4-nitrofurazan 4 crystallizes in the orthorhombic space group Pbca with a cell volume of $1177.45 \AA^{3}$ and eight molecular units per unit cell. The calculated density at $173 \mathrm{~K}$ is $1.975 \mathrm{~g} \cdot \mathrm{cm}^{-3}$, which is comparable to the density reported in the literature: $1.93 \mathrm{~g} \cdot \mathrm{cm}^{-3}$ (gas pycnometer) [5] and $1.95 \mathrm{~g} \cdot \mathrm{cm}^{-3}$ [7]. The small discrepancies are likely due to the different temperatures at which the densities were measured. The molecular unit of $\mathbf{4}$ is displayed in Figure 3.

The nitro- and nitramino groups in compound $\mathbf{4}$ are only slightly tilted against the furazan ring as shown by the torsion angles $\mathrm{O} 4-\mathrm{B} 5-\mathrm{C} 2-\mathrm{C} 1=4.2^{\circ}, \mathrm{C} 1-\mathrm{N} 3-\mathrm{N} 4-\mathrm{O} 2=179.4^{\circ}$ and $\mathrm{C} 1-\mathrm{N} 3-\mathrm{N} 4-\mathrm{O} 2=3.9^{\circ}$. Together with the planar furazan ring $\left(\mathrm{N} 2-\mathrm{O} 1-\mathrm{N} 1-\mathrm{C} 1=0.5^{\circ}\right)$ the complete compound forms an almost planar unit, which might be one of the reasons that can explain the high density of this compound. Another reason might be the hydrogen-bonds of N3-H3...O4 and N3-H3...O3. The bond distances of the furazan ring $(\mathrm{C} 1-\mathrm{C} 2=1.420 \AA)$ and the nitro group (N5-C2 $1.444 \AA$, O5-N5 = $1.215 \AA$ ) are similar to those in other nitrofurazanes as compound 3. The bond distances of the nitramino moiety $(\mathrm{O} 2-\mathrm{N} 4=1.210 \AA, \mathrm{N} 3-\mathrm{N} 4=1.370 \AA)$ are also in the same range compared to other nitramino moieties in heterocyclic ring systems $[6,12]$.

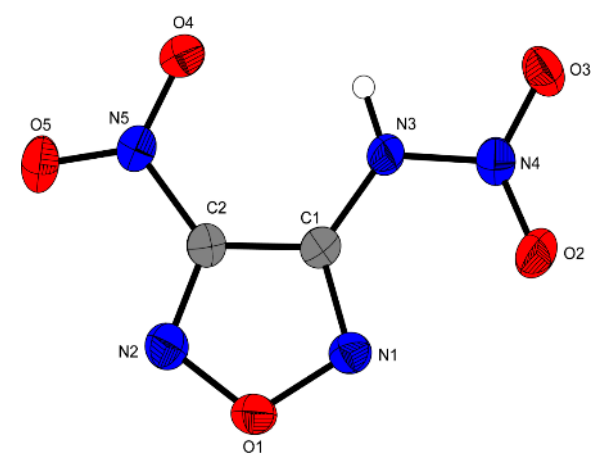

Figure 3. Molecular unit of 4. Ellipsoids are drawn at the $50 \%$ probability level. Selected bond distances ( $\AA$ ): O2-N4 1.210(2), N3-N4 1.370(2), N3-C1 1.365(2), N5-C2 1.444(2), O5-N5 1.215(2), C1-C2 1.420(3); selected bond angles $\left(^{\circ}\right)$ : N2-C2-N5 111.23 (17), N3-C1-C2 107.69(16), N1-O1-N2 112.26(14); selected hydrogen bond distances $[\AA]$ and angles $\left[^{\circ}\right](\mathrm{D}-\mathrm{H} \cdots \mathrm{A}, \mathrm{d}(\mathrm{D}-\mathrm{H}), \mathrm{d}(\mathrm{H} \ldots \mathrm{A}), \mathrm{d}(\mathrm{D} \ldots \mathrm{A}),(\mathrm{D}-\mathrm{H} \ldots \mathrm{A}))$ : N3-H3...O4: 0.85(3), 2.29(2), 2.787(2), 111.8(2); N3-H3 ...O3 0.85(3), 2.21(3), 3.016(2), 159(2); selected torsion angles $\left({ }^{\circ}\right)$ : $\mathrm{N} 2-\mathrm{O} 1-\mathrm{N} 1-\mathrm{C} 1 \quad 0.5(2), \quad \mathrm{O} 4-\mathrm{B} 5-\mathrm{C} 2-\mathrm{C} 1 \quad 4.2(3), \mathrm{C} 1-\mathrm{N} 3-\mathrm{N} 4-\mathrm{O} 2$ 179.4(2), C1-N3-N4-O2 $3.9(3)$.

Hydroxylammonium 3-nitramino-4-nitrofurazan 5 crystallizes in the monoclinic space group Pc with a cell volume of $361.86 \AA^{3}$ and two molecular units per unit cell. The calculated density at $173 \mathrm{~K}$ is $1.910 \mathrm{~g} \cdot \mathrm{cm}^{-3}$, which is comparable to the reported values in the literature: $1.875 \mathrm{~g} \cdot \mathrm{cm}^{-3}$ (X-ray analysis) [5] and $1.89 \mathrm{~g} \cdot \mathrm{cm}^{-3}$ [7]. The slightly higher density values of 5 might be because of the different temperatures at which the densities were measured. The molecular unit of $\mathbf{5}$ is displayed in Figure 4.

Similar to neutral compound 4, the furazan unit in $\mathbf{5}$ is planar $\left(\mathrm{N} 2-\mathrm{O} 2-\mathrm{N} 1-\mathrm{C} 1=1.1^{\circ}\right)$, whereas the nitro- and nitramino groups are slightly tilted against the furazan ring as indicated by the torsion angles of O5-N5-C2-N2 $=5.1^{\circ}$ and N4-N3-C1-C2 $=171.7^{\circ}, \mathrm{C} 1-\mathrm{N} 3-\mathrm{N} 4-\mathrm{O} 3=2.5^{\circ}$. Hydrogen-bonding can for example be observed between the hydrogen atoms of the hydroxylammonium cation and the $\mathrm{O} 4$ of the nitramino moiety. The bond distances of the furazan ring $(\mathrm{C} 1-\mathrm{C} 2=1.432 \AA)$, the nitro group 
$(\mathrm{N} 5-\mathrm{C} 2=1.451 \AA, \mathrm{O} 6-\mathrm{N} 5=1.243 \AA)$ and the nitramino moiety $(\mathrm{N} 3-\mathrm{N} 4=1.307 \AA$, O4-N4 = 1.280 $\AA$ ) are in accordance with parent compound 4.

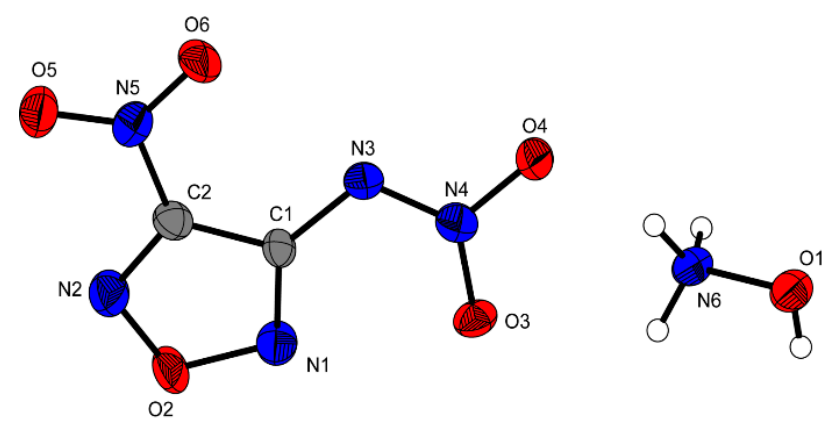

Figure 4. Molecular unit of 5. Ellipsoids are drawn at the 50\% probability level. Selected bond distances (Å): N5-C2 1.451(8), O6-N5 1.243(6), N3-C1 1.385(7), N3-N4 1.307(2), O4-N4 1.280(6), C1-C2 1.432(8); selected bond angles $\left(^{\circ}\right)$ : $\mathrm{N} 1-\mathrm{O} 2-\mathrm{N} 2$ 111.8(4), N2-C2-N5 119.7(5), N1-C1-N3 129.7(5), O3-N4-N3 125.5(5); selected hydrogen bond distances $[\AA]$ and angles $\left[^{\circ}\right](\mathrm{D}-\mathrm{H} \ldots \mathrm{A}, \mathrm{d}(\mathrm{D}-\mathrm{H}), \mathrm{d}(\mathrm{H} \ldots \mathrm{A}), \mathrm{d}(\mathrm{D} \ldots \mathrm{A}),(\mathrm{D}-\mathrm{H} \ldots \mathrm{A}))$ : N6-H6B...O4: 0.910, 2.440, 2.892(6), 111.00; O1-H4A...O4 0.73(6), 1.94(6), 2.653(6), 169(6); selected torsion angles $\left(^{\circ}\right)$ : $\mathrm{N} 2-\mathrm{O} 2-\mathrm{N} 1-\mathrm{C} 1$ 1.1(6), O5-N5-C2-N2 5.1(8), N4-N3-C1-C2 171.7(5), C1-N3-N4-O3 2.5(8).

Ammonium 3-nitramino-4-nitrofurazan 6 crystallizes in the monoclinic space group $P 21 / n$ with a cell volume of $704.59 \AA^{3}$ and four molecular units per unit cell. The calculated density at $173 \mathrm{~K}$ is $1.811 \mathrm{~g} \cdot \mathrm{cm}^{-3}$, which is virtually the same as the reported density in the literature: $1.82 \mathrm{~g} \cdot \mathrm{cm}^{-3}$ [7], but significantly lower than of hydroxylammonium salt $\mathbf{5}$. The molecular unit of compound $\mathbf{6}$ is illustrated in Figure 5.

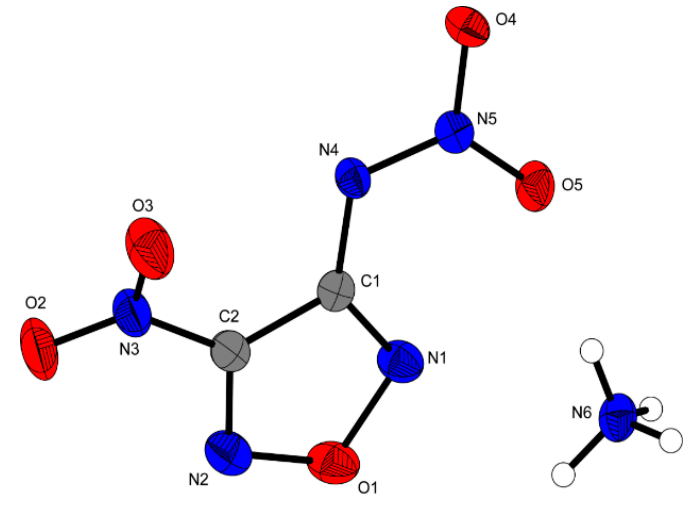

Figure 5. Molecular unit of 6. Ellipsoids are drawn at the 50\% probability level. Selected bond distances $(\AA)$ : $\quad \mathrm{C} 1-\mathrm{C} 2 \quad 1.4293(17), \quad \mathrm{N} 3-\mathrm{C} 2 \quad 1.451(2), \quad \mathrm{O} 3-\mathrm{N} 3 \quad 1.217(2)$, N4-C1 1.3684(15), N4-N5 1.3179(15), O4-N4 1.2570(14); selected bond angles $\left(^{\circ}\right)$ : N1-O1-N2 111.72(10), N2-C2-N3 119.64(11), N1-C1-N4 132.09(11), O5-N5-N4 124.25(11); selected hydrogen bond distances $[\AA]$ and angles $\left[{ }^{\circ}\right](\mathrm{D}-\mathrm{H} . . \mathrm{A}$, $\mathrm{d}(\mathrm{D}-\mathrm{H}), \mathrm{d}(\mathrm{H} \ldots \mathrm{A}), \mathrm{d}(\mathrm{D} \ldots \mathrm{A}),(\mathrm{D}-\mathrm{H} \ldots \mathrm{A}))$ : N6-H4A...O3: 0.87(2), 2.51(3), 3.249 (2), 143(2); N6-H4A...O2: 0.87(2), 2.38(3), 3.043 (2), 133.6(18); N4-H4B...O5 0.91(2), 2.09(2), 2.993(2), 176(2); selected torsion angles $\left(^{\circ}\right)$ : $\mathrm{N} 2-\mathrm{O} 1-\mathrm{N} 1-\mathrm{C} 1 \quad 0.27(14)$, N5-N4-C1-N1 5.5(2), O2-N3-C2-N2 29.5(2), C1-N4-N5-O5 2.9(2). 
As in salt 5 and neutral compound 4, the furazan ring in $\mathbf{6}$ has a planar structure $\left(\mathrm{N} 2-\mathrm{O} 1-\mathrm{N} 1-\mathrm{C} 1=0.27^{\circ}\right.$. While the nitramino group is only slightly tilted against the furazan plane $\left(\mathrm{N} 5-\mathrm{N} 4-\mathrm{C} 1-\mathrm{N} 1=5.5^{\circ}, \mathrm{C} 1-\mathrm{N} 4-\mathrm{N} 5-\mathrm{O} 5=2.9^{\circ}\right)$, the nitro group is tilted strongly against the plane by a torsion angle of $\mathrm{O} 2-\mathrm{N} 3-\mathrm{C} 2-\mathrm{N} 2=29.5^{\circ}$. A reason for this might be the strong hydrogen bonds between the hydroxylammonium cation and the oxygen atoms $\mathrm{O} 3$ and $\mathrm{O} 4$ of the nitro group. More hydrogen bonds can be observed between the cation and the nitramino moiety. Even though the nitro group is strongly tilted against the plane, the bond distances of the furazan ring $(\mathrm{C} 1-\mathrm{C} 2=1.4293 \AA)$, the nitro group $(\mathrm{N} 3-\mathrm{C} 2=1.451 \AA, \mathrm{O} 3-\mathrm{N} 3=1.217 \AA)$ and nitramino moiety $(\mathrm{N} 4-\mathrm{N} 5=1.3179 \AA$, O4-N4 = $1.257 \AA$ ) are comparable to parent compound $\mathbf{4}$ and salt 5.

Compound 3,6,7-Triamino-[1,2,4]triazolo[4,3-b][1,2,4]triazolium 3-nitramino-4-nitrofurazan 8 crystallizes in the monoclinic space group $P 21$ with a cell volume of $619.21 \AA^{3}$ and two molecular units per unit cell. The calculated density at $173 \mathrm{~K}$ is $1.766 \mathrm{~g} \cdot \mathrm{cm}^{-3}$, which is lower than the density of salts 5 and 6. The molecular unit of compound $\mathbf{8}$ is shown in Figure 6.

In compound 8 , the furazan ring is also planar $\left(\mathrm{N} 2-\mathrm{O} 1-\mathrm{N} 1-\mathrm{C} 1=0.27^{\circ}\right)$, whereas the nitro $\left(\mathrm{O} 5-\mathrm{N} 3-\mathrm{C} 2-\mathrm{C} 1=157.9^{\circ}\right)$ and nitramino $\left(\mathrm{N} 5-\mathrm{N} 4-\mathrm{C} 1-\mathrm{C} 2=50.6^{\circ}, \mathrm{O} 2-\mathrm{N} 5-\mathrm{N} 4-\mathrm{C} 1=7.4^{\circ}\right)$ moieties are strongly tilted out of the furazan plane. The cation has a planar structure except for the two protons located at N13 as reported previously in the literature [4]. All the three amino groups in the cation form hydrogen bonds to the nitro and nitramino groups of the anion, resulting in a strong hydrogen-bonding network. This effect was expected because it was already observed for other energetic salts of the 3,6,7-triamino-[1,2,4]triazolo[4,3-b][1,2,4]triazolium cation [4] and can explain the higher thermal stability of compound 8 compared to that of salts $\mathbf{5}$ and $\mathbf{6}$. The bond distances of the furazan ring $(\mathrm{C} 1-\mathrm{C} 2=1.422 \AA)$, the nitro group $(\mathrm{C} 2-\mathrm{N} 3=1.441 \AA$, O4-N3 = $1.211 \AA)$ and the nitramino group $(\mathrm{O} 3-\mathrm{N} 5=1.227 \AA, \mathrm{N} 4-\mathrm{N} 5=1.300 \AA)$ are virtually the same as in parent compound 4 or salts 5 and $\mathbf{6}$. The bond distances of the cation fit the values of the literature [4].
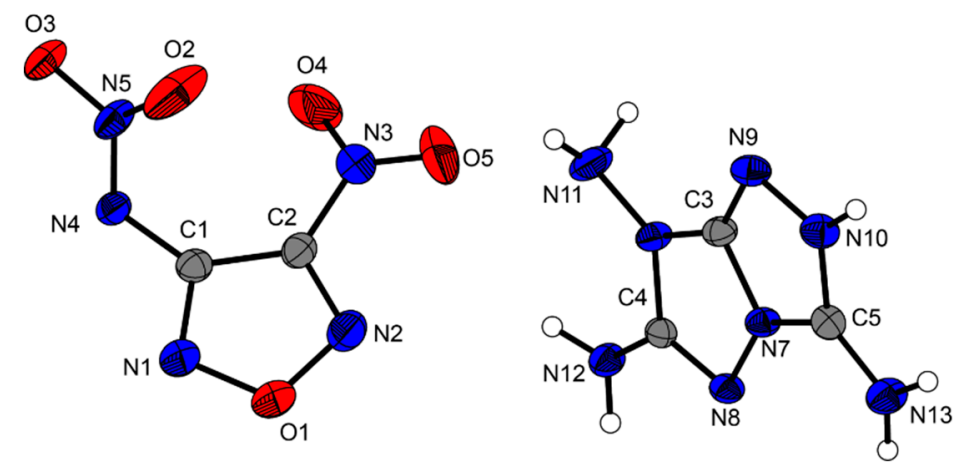

Figure 6. Molecular unit of $\mathbf{8}$. Ellipsoids are drawn at the $50 \%$ probability level. Selected bond distances ( $\AA$ ): C1-C2 1.422(3), N4-C1 1.381(3), N4-N5 1.300(3), O3-N5 1.277(3), C2-N3 1.441(3), O4-N3 1.211(3); selected bond angles $\left(^{\circ}\right)$ : N1-O1-N2 111.64(19), N2-C2-N3 138.4(2), O2-N5-N4 123.3(2), N4-C1-C2 134.1(2); selected hydrogen bond distances $[\AA]$ and angles $\left[^{\circ}\right](\mathrm{D}-\mathrm{H} \ldots \mathrm{A}, \mathrm{d}(\mathrm{D}-\mathrm{H}), \mathrm{d}(\mathrm{H} \ldots \mathrm{A}), \mathrm{d}(\mathrm{D} \ldots \mathrm{A}),(\mathrm{D}-\mathrm{H} \ldots \mathrm{A}))$ : N10-H10...O3: 0.79(3), 2.08(3), 2.869(2), 175(3); N11-H11A...N2 0.87(4), 2.42(4), 3.190(3), 148(3); N12-H12A...O5 0.88(3), 2.58(3), 3.345(3), 147(3); selected torsion angles $\left({ }^{\circ}\right)$ : N2-O1-N1-C1 1.2(3), O2-N5-N4-C1 7.4(4), N5-N4-C1-C2 50.6(4), O5-N3-C2-C1 157.9(2). 
Di-3,6,7-triamino-[1,2,4]triazolo[4,3-b][1,2,4]triazolium dinitraminoazoxyfurazan 12 crystallizes in the triclinic space group $P-1$ with a cell volume of $561.13 \AA^{3}$ and one molecular units per unit cell. The calculated density at $173 \mathrm{~K}$ is $1.807 \mathrm{~g} \cdot \mathrm{cm}^{-3}$, which is somewhat lower than the density of the corresponding hydroxylammonium salt: $1.883 \mathrm{~g} \cdot \mathrm{cm}^{-3}$ (X-ray analysis at $173 \mathrm{~K}$ ). [6] The molecular unit of compound 12 is displayed in Figure 7.

In compound 12, the $\mathrm{N}=\mathrm{N}$ connected furazan rings are tilted against each other by a torsion angle of $38.2^{\circ}(\mathrm{N} 3 \mathrm{i}-\mathrm{N} 3-\mathrm{NC} 2-\mathrm{C} 1) . \mathrm{O} 4$ is in the same plane as the furazan ring which is located further away $\left(\mathrm{O} 4-\mathrm{N} 3-\mathrm{C} 3 \mathrm{i}-\mathrm{C} 2 \mathrm{i}=1.0^{\circ}\right)$ and twisted against the furazan ring which is closer to $\mathrm{O} 4\left(\mathrm{O} 4-\mathrm{N} 3-\mathrm{C} 2-\mathrm{C} 1=37.0^{\circ}\right)$. The two nitramino moieties are also tilted out of the furazan plane by $44.0^{\circ}$ (N6-N5-C1-C2). The two cations have a planar structure except for the two protons located at $\mathrm{N} 13$ as reported previously in the literature [4]. As in salt 8, an intensive hydrogen bond network is formed between the three amino groups of the cation and the nitro and nitramino groups of the anion, which makes the salt 12 stable up to $266{ }^{\circ} \mathrm{C}$ The bond distances of the anion $(\mathrm{C} 1-\mathrm{C} 2=1.432 \AA$, $\mathrm{N} 5-\mathrm{C} 1=1.380 \AA, \mathrm{N} 5-\mathrm{N} 6=1.306 \AA, \mathrm{O} 2-\mathrm{N} 6=1.244 \AA, \mathrm{C} 2-\mathrm{N} 3=1.416 \AA, \mathrm{N} 3-\mathrm{O} 4=1.199 \AA$ ), are in accordance with other dinitraminoazoxyfurazanes [6]. The bond distances of the cation are in good agreement with literature values. [4]

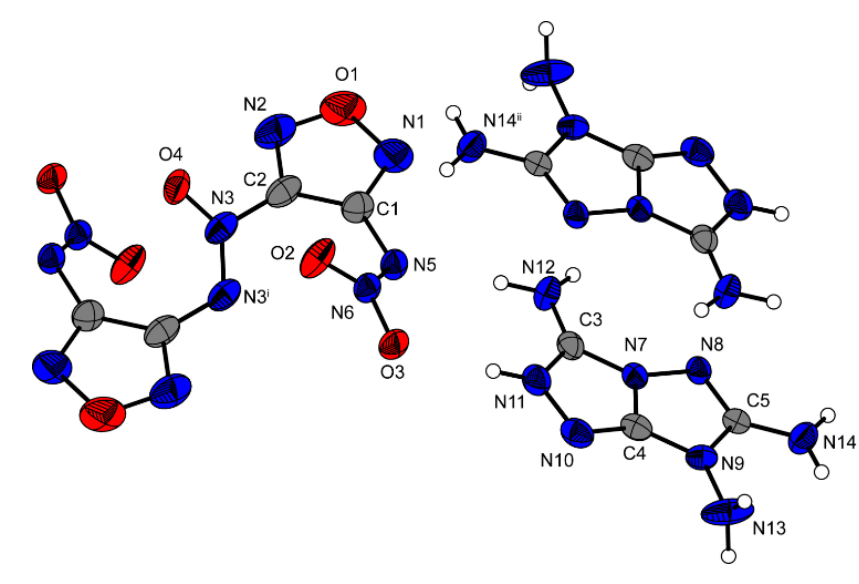

Figure 7. Molecular unit of 12. Ellipsoids are drawn at the 50\% probability level. Selected bond distances ( $\AA$ ): C1-C2 1.432(4), N5-C1 1.380(3), N5-N6 1.306(3), O2-N6 1.244(3), C2-N3 1.416(4), N3-O4 1.199(4), N3-N3i 1.268(3); selected bond angles $\left(^{\circ}\right)$ : N3i-N3-C2 115.2(2), N4-N3-C2 111.9(3), N6-N5-C1 113.2(2); selected hydrogen bond distances $[\AA]$ and angles $\left[^{\circ}\right](\mathrm{D}-\mathrm{H} \ldots \mathrm{A}, \mathrm{d}(\mathrm{D}-\mathrm{H}), \mathrm{d}(\mathrm{H} \ldots \mathrm{A}), \mathrm{d}(\mathrm{D} \ldots \mathrm{A}),(\mathrm{D}-\mathrm{H} \ldots \mathrm{A}))$ : N11-H11...O3: 0.89(2), 1.95(3), 2.814(3), 164(3); N12-H12A...N5 0.90(4), 2.11(2), 3.001(3), 171(3); N12-H12B...O2 0.86(4), 2.48(3), 3.163(3), 137(3); selected torsion angles $\left(^{\circ}\right)$ : N3i-N3-C2-C1 38.2(4), O4-N3-C3i-C2i 1.0(4), O4-N3-C2-C1 37.0(4), N6-N5-C1-C2 44.0(4), C1-N5-N6-O2 5.7(3).

\subsection{Thermal Analysis and Sensitivities}

Considering safety issues explosives should be heat resistant. To identify the decomposition temperatures of compounds 3-12, differential thermal analysis (DTA) with a heating rate of $5{ }^{\circ} \mathrm{C} \cdot \mathrm{min}^{-1}$ was used. The results are shown in Figure 8 . The decomposition temperatures are given as absolute onset temperatures. 
Compound 3 decomposes at $143{ }^{\circ} \mathrm{C}$, whereas 3-nitramino-4-nitrofurazan 4 as well as its hydroxylammonium 5 and hydrazinium salt 6 decompose between $65{ }^{\circ} \mathrm{C}$ and $140{ }^{\circ} \mathrm{C}$. The thermal stability of 3-nitramino-4-nitrofurazan could be enhanced by introducing thermally stable cations as demonstrated by compounds 7 and 8 with a decomposition onset at $176{ }^{\circ} \mathrm{C}$ and $193{ }^{\circ} \mathrm{C}$. Moreover compounds 11 and 12 surpass a decomposition temperature of $200{ }^{\circ} \mathrm{C}$, which can be considered as benchmark for new potential secondary explosives.

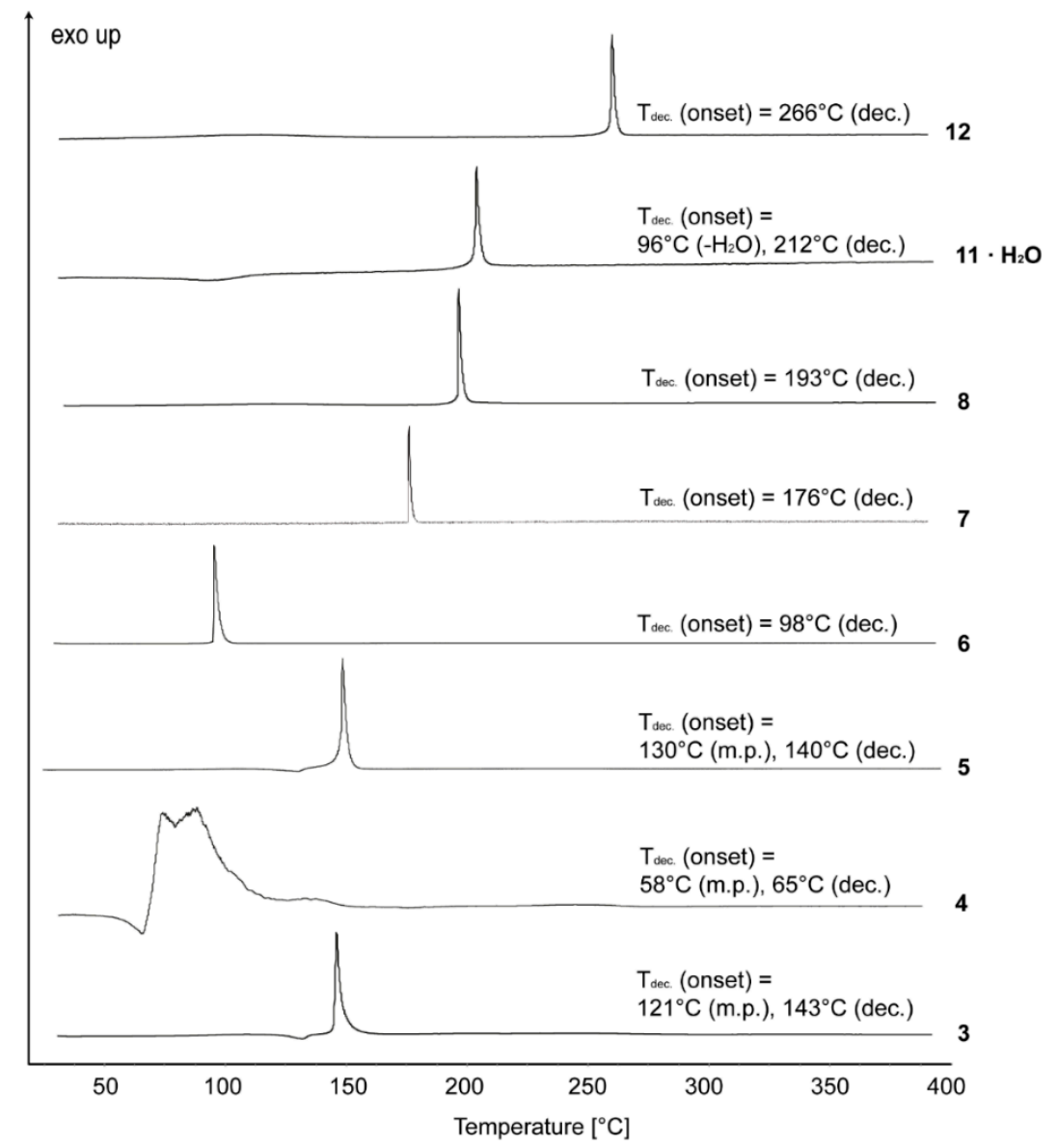

Figure 8. Differential thermal analysis (DTA) plots of compounds 3-12 measured with a heating rate of $5^{\circ} \mathrm{C} \cdot \mathrm{min}^{-1}$.

Sensitivities of compounds 3-12 were determined and are displayed in Table 1. The impact sensitivities for the derivatives of 3-nitramino-4-nitrofurazan 4 range from $3 \mathrm{~J}$ (7) to $10 \mathrm{~J}(5)$. The two energetic salts of dinitraminoazoxyfurazan $\mathbf{1 0}$ show similar and slightly lower impact sensitivities with $15 \mathrm{~J}$ (11) and $10 \mathrm{~J}$ (12). The friction sensitivities lie between $120 \mathrm{~N}$ (4) and $360 \mathrm{~N}$ (12), except for the hydroxylammonium 5 and ammonium 6 salt, both of which comprise a friction sensitivity of $72 \mathrm{~N}$.

Although all structures are dominated by a large variety of hydrogen bonds and other electrostatic interactions all investigated compounds were found to be sensitive toward various outer stimuli. Except for energetic polymorphs in our opinion it is still very challenging to correlate sensitivities and structural motives. For neutral compounds some strategies have been described e.g. by Politzer et al. They correlated impact sensitivity versus electrostatic surface potentials or molecular volumes [13]. However, these methods have not successfully been applied for energetic salts, which deviate significantly from standard energetic motifs, such as those found in traditional explosives, such as TNT and RDX. 


\subsection{Physiochemical and Energetic Properties}

The heats and energies of formation are given in Table 1. Calculation of the detonation parameters as detonation velocity $D$ and detonation pressure $p_{\mathrm{CJ}}$ was performed with the program package EXPLO5 (version 6.02) [14]. The EXPLO5 detonation parameters of compounds 2-12 were calculated by using pycnometrical measured densities of the water free compounds or the room-temperature density values obtained from the X-ray structures as described in Table 1 and in reference [15]. For a complete discussion on the methods used see the Supporting Information.

Table 1. Physico-chemical properties properties of compounds 3-8 and 11-12 compared with those of Research Department explosive (RDX).

\begin{tabular}{|c|c|c|c|c|c|c|c|c|c|}
\hline & 3 & 4 & 5 & 6 & 7 & 8 & 11 & 12 & RDX \\
\hline Formula & $\mathrm{C}_{2} \mathrm{H}_{2} \mathrm{~N}_{4} \mathrm{O}_{3}$ & $\mathrm{C}_{2} \mathrm{HN}_{5} \mathrm{O}_{5}$ & $\mathrm{C}_{2} \mathrm{H}_{4} \mathrm{~N}_{6} \mathrm{O}_{6}$ & $\mathrm{C}_{2} \mathrm{H}_{4} \mathrm{~N}_{6} \mathrm{O}_{5}$ & $\mathrm{C}_{8} \mathrm{H}_{10} \mathrm{~N}_{20} \mathrm{O}_{10}$ & $\mathrm{C}_{5} \mathrm{H}_{7} \mathrm{~N}_{13} \mathrm{O}_{5}$ & $\mathrm{C}_{8} \mathrm{H}_{10} \mathrm{~N}_{20} \mathrm{O}_{7}$ & $\mathrm{C}_{10} \mathrm{H}_{14} \mathrm{~N}_{26} \mathrm{O}_{7}$ & $\mathrm{C}_{3} \mathrm{H}_{6} \mathrm{~N}_{6} \mathrm{O}_{6}$ \\
\hline $\mathrm{FW}\left[\mathrm{g} \cdot \mathrm{mol}^{-1}\right]$ & 130.06 & 175.06 & 208.09 & 192.09 & 546.29 & 329.19 & 498.29 & 610.39 & 222.12 \\
\hline$I S[\mathrm{~J}]^{a}$ & 10 & 4 & 10 & 7 & 3 & 6 & 15 & 10 & 7.5 \\
\hline$F S[\mathrm{~N}]^{b}$ & 360 & 120 & 72 & 72 & 252 & 324 & 240 & 360 & 120 \\
\hline $\operatorname{ESD}[\mathrm{J}]^{c}$ & 0.3 & 0.3 & 0.5 & 0.8 & 0.75 & 1.2 & 0.25 & 0.5 & 0.20 \\
\hline$N[\%]^{d}$ & 43.08 & 40.01 & 40.39 & 43.75 & 51.28 & 55.31 & 56.22 & 59.66 & 37.84 \\
\hline$\Omega[\%]^{e}$ & -24.60 & -4.57 & 0.00 & -8.33 & -32.22 & -41.31 & -44.95 & -52.43 & -21.61 \\
\hline$T_{\text {dec. }}\left[{ }^{\circ} \mathrm{C}\right]^{f}$ & $\begin{array}{l}\text { 121(m.p.) } \\
143 \text { (dec.) }\end{array}$ & $\begin{array}{l}\text { 58(m.p.) } \\
65 \text { (dec.) }\end{array}$ & 140 & 98 & 176 & 193 & 212 & 266 & 210 \\
\hline $\begin{array}{c}\rho\left[\mathrm{g} \cdot \mathrm{cm}^{-3}\right] \\
(298 \mathrm{~K})^{g}\end{array}$ & 1.808 & 1.939 & 1.875 & 1.778 & $\begin{array}{c}1.69 \\
\text { (pyc.) }\end{array}$ & 1.733 & $\begin{array}{c}1.79 \\
\text { (pyc.) }\end{array}$ & 1.774 & 1.806 \\
\hline $\begin{array}{c}\Delta_{\mathrm{f}} H^{\circ} \\
{\left[\mathrm{kJ} \cdot \mathrm{mol}^{-1}\right]^{h}}\end{array}$ & 156.7 & 263.6 & 254.7 & 199.9 & 834.1 & 715.9 & 715.4 & 1706.7 & 70.3 \\
\hline $\begin{array}{c}\Delta_{\mathrm{f}} U^{\circ} \\
{\left[\mathrm{kJ} \cdot \mathrm{kg}^{-1}\right]^{i}}\end{array}$ & 1290.7 & 1583.7 & 1319.3 & 1137.4 & 1617.6 & 2268.9 & 1527.8 & 2891.6 & 417.0 \\
\hline
\end{tabular}

\begin{tabular}{cccccccccc}
$-\Delta_{E} U^{\circ}$ & 5712 & 6555 & 7018 & 6348 & 5262 & 5484 & 4578 & 5538.7 & 5845 \\
{$\left[\mathrm{~kJ} \cdot \mathrm{kg}^{-1}\right]^{j}$} & & & & & & & & & \\
$T_{\mathrm{E}}[\mathrm{K}]^{k}$ & 4015 & 4768 & 4627 & 4292 & 3790 & 3760 & 3253 & 3658.5 & 3810 \\
$p_{\mathrm{CJ}}[\mathrm{kbar}]^{l}$ & 333 & 398 & 407 & 349 & 277 & 297 & 286 & 311 & 345 \\
$D\left[\mathrm{~m} \mathrm{~s}^{-1}\right]^{m}$ & 8769 & 9438 & 9589 & 9011 & 8330 & 8649 & 8580 & 8965 & 8861 \\
$V_{0}\left[\mathrm{~L} \mathrm{~kg}^{-1}\right]^{n}$ & 743 & 733 & 815 & 810 & 788 & 796 & 780 & 800 & 785 \\
\hline
\end{tabular}

${ }^{a}$ impact sensitivity (BAM (Bundesanstalt für Materialforschung und -prüfung) drophammer, 1 of 6); ${ }^{b}$ friction sensitivity (BAM friction tester, 1 of 6$) ;{ }^{c}$ electrostatic discharge device (OZM); ${ }^{d}$ nitrogen content; ${ }^{e}$ oxygen balance; ${ }^{f}$ decomposition temperature from DSC $\left(\beta=5{ }^{\circ} \mathrm{C}\right) ;{ }^{g}$ recalculated from low temperature X-ray densities $\left(\rho_{298 \mathrm{~K}}=\rho_{\mathrm{T}} /\left(1+\alpha_{\mathrm{V}}\left(298-\mathrm{T}_{0}\right) ; \alpha_{\mathrm{V}}=1.510^{-4} \mathrm{~K}^{-1}\right)[16] ;{ }^{h}\right.$ calculated $(\mathrm{CBS}-4 \mathrm{M})$ heat of formation; ${ }^{i}$ calculated energy of formation; ${ }^{j}$ energy of explosion; ${ }^{k}$ explosion temperature; ${ }^{l}$ detonation pressure; ${ }^{m}$ detonation velocity; ${ }^{n}$ assuming only gaseous products.

The densities range from $1.69 \mathrm{~g} \cdot \mathrm{cm}^{-3}(7)$ to $1.939 \mathrm{~g} \cdot \mathrm{cm}^{-3}(4)$ and are summarized in Table 1 with the calculated explosion parameters for 3-8 and 11-12, alongside a comparison with the values calculated for RDX. The recalculated low temperature X-ray densities of compounds 4-6 have only small deviation compared to the values reported in the literature: $1.939 \mathrm{~g} \cdot \mathrm{cm}^{-3}$ (4) versus $1.93 \mathrm{~g} \cdot \mathrm{cm}^{-3}$ (gas pycnometer) [5] 
and $1.95 \mathrm{~g} \cdot \mathrm{cm}^{-3}$ [7]; $1.875 \mathrm{~g} \cdot \mathrm{cm}^{-3}$ (5) versus $1.875 \mathrm{~g} \cdot \mathrm{cm}^{-3}$ (X-ray analysis) [5] and $1.89 \mathrm{~g} \cdot \mathrm{cm}^{-3}$ [7]; $1.778 \mathrm{~g} \cdot \mathrm{cm}^{-3} 6$ versus $1.82 \mathrm{~g} \cdot \mathrm{cm}^{-3}[7]$.

All compounds reported in Table 1 show a highly positive heat of formation from $156.7 \mathrm{~kJ} \cdot \mathrm{mol}^{-1}(3)$ to $1706.7 \mathrm{~kJ} \cdot \mathrm{mol}^{-1}(\mathbf{1 2})$, which are all higher than the heat of formation of RDX $\left(70.3 \mathrm{~kJ} \cdot \mathrm{mol}^{-1}\right)$. The high heat of formation of salt 12 can be explained by the large number of $\mathrm{N}-\mathrm{N}$ bonds.

The detonation velocities and pressures range from $D=8330 \mathrm{~m} \cdot \mathrm{s}^{-1}(7)-9589 \mathrm{~m} \cdot \mathrm{s}^{-1}$ (5) and $p_{\mathrm{CJ}}=277 \mathrm{kbar}(7)-407 \mathrm{kbar}(5)$. Notably is the discrepancy between the calculated detonation velocities and pressures compared to the previously reported values in the literature:[7] $D=9438 \mathrm{~m} \cdot \mathrm{s}^{-1}$ (4) versus $D=9860 \mathrm{~m} \cdot \mathrm{s}^{-1}$ (lit.), $D=9589 \mathrm{~m} \cdot \mathrm{s}^{-1}$ (5) vs. $D=10010 \mathrm{~m} \cdot \mathrm{s}^{-1}$ (lit.), $D=9011 \mathrm{~m} \cdot \mathrm{s}^{-1}$ (6) versus $D=9880 \mathrm{~m} \cdot \mathrm{s}^{-1}$ (lit.), $p_{\mathrm{CJ}}=398 \mathrm{kbar}(4)$ versus $p_{\mathrm{CJ}}=464 \mathrm{kbar}$ (lit.), $p_{\mathrm{CJ}}=407 \mathrm{kbar}$ (5) versus $p_{\mathrm{CJ}}=478 \mathrm{kbar}$ (lit.), $p_{\mathrm{CJ}}=349 \mathrm{kbar}(6)$ versus $p_{\mathrm{CJ}}=465 \mathrm{kbar}$ (lit.). A potential reason for these discrepancies are the different computer codes used for the calculation of the detonation parameters [17]. The thermally stable salt $\mathbf{1 2}$ shows a detonation velocity comparable to that of RDX.

\section{Experimental Section}

Compound $\mathbf{9}$ and $\mathbf{1 0}$ were prepared as described in the literature $[6,10]$.

\subsection{3-Amino-4-Nitrofurazan (3)}

Compound 3 was synthesized according to the literature [9].

DTA $\left(5{ }^{\circ} \mathrm{C} \cdot \mathrm{min}^{-1}\right)$ onset: $121{ }^{\circ} \mathrm{C}(\mathrm{m}),. 143{ }^{\circ} \mathrm{C}$ (dec.), literature: $120{ }^{\circ} \mathrm{C}(\mathrm{m}),. 170{ }^{\circ} \mathrm{C}(\mathrm{dec}$.$) [9]; IR$ $\left(\right.$ ATR, $\left.\mathrm{cm}^{-1}\right): v=3471(\mathrm{~m}), 3447(\mathrm{~m}), 3337(\mathrm{~m}), 2957$ (w), 2923 (w), 2854 (w), 1717 (w), 1634 (s), $1521(\mathrm{~s})$, 1499(s), 1464 (m), 1436 (m), 1369 (vs), 1348 (s), 1230 (w), 1210 (s), 1097 (m), 1039 (s), 870 (w), 832 (vs), $764(\mathrm{~m}), 728(\mathrm{w}), 680(\mathrm{w}), 662(\mathrm{w}) ;{ }^{1} \mathrm{H}$ NMR ([D6]DMSO, ppm): $\delta=6.98\left(\mathrm{~s}, 2 \mathrm{H},-\mathrm{NH}_{2}\right)$; ${ }^{13} \mathrm{C}$ NMR ([D6]DMSO, ppm): $\delta=153.3\left(\mathrm{C}-\mathrm{NO}_{2}\right), 151.5\left(\mathrm{C}-\mathrm{NH}_{2}\right) ;{ }^{14} \mathrm{~N}$ NMR ([D6]DMSO, ppm): $\delta=-28.8\left(\mathrm{C}-\mathrm{NO}_{2}\right) ; m / z\left(\mathrm{DEI}^{+}\right): 130.1\left(\mathrm{C}_{2} \mathrm{H}_{2} \mathrm{~N}_{4} \mathrm{O}_{3}\right) ; \mathrm{EA}\left(\mathrm{C}_{2} \mathrm{H}_{2} \mathrm{~N}_{4} \mathrm{O}_{3}, 130.06\right)$ : C 18.47, H 1.55, N 43.08, found: C 18.64, H 1.69, N 43.05; BAM impact: $10 \mathrm{~J}$; BAM friction: $360 \mathrm{~N}$; ESD: $0.3 \mathrm{~J}$.

\subsection{3-Nitramino-4-nitrofurazan (4)}

Compound 4 was synthesized via a revised literature procedure [5].

A dry $100 \mathrm{ml}$ three-neck flask was equipped with a stirrer, thermometer and two stoppers. $60-70 \mathrm{~mL}$ of methylene chloride was added and cooled to $-20{ }^{\circ} \mathrm{C}$. To the cooled methylene chloride was added $\mathrm{N}_{2} \mathrm{O}_{5}$ (2.3 g, $21.3 \mathrm{mmol}, 1.2$ equiv.). When the $\mathrm{N}_{2} \mathrm{O}_{5}$ was fully dissolved, 3 (2.3 g, $17.7 \mathrm{mmol}$, 1.0 equiv.) was added slowly over a period of $2-5$ minutes, while the temperature was kept at $-20{ }^{\circ} \mathrm{C}$. The yellowish solution was put in ice bath and warmed slowly to $0-5{ }^{\circ} \mathrm{C}$, then it was stirred for $3 \mathrm{~h}$ at $0-5{ }^{\circ} \mathrm{C}$. The solvents were removed under a constant nitrogen flow to yield $2.04 \mathrm{~g}(11.65 \mathrm{mmol}, 66 \%)$ of 4 .

DTA $\left(5{ }^{\circ} \mathrm{C} \cdot \mathrm{min}^{-1}\right)$ onset: $65{ }^{\circ} \mathrm{C}$ (dec.), literature: $60{ }^{\circ} \mathrm{C}(\mathrm{m}),. 101.5{ }^{\circ} \mathrm{C}\left(\mathrm{dec}\right.$.) [5]; IR (ATR, $\left.\mathrm{cm}^{-1}\right)$ : $v=3617(\mathrm{vw}), 3271(\mathrm{~m}), 2930(\mathrm{w}), 2714$ (w), 1625 (s), 1604 (s), 1545 (m), 1496 (vs), 1378 (m), 1329 (vs), 1302 (vs), 1201 (m); 1177 (s), 1168 (m), 1053 (m), 997 (m), 942 (s), 888 (w), 836 (s), 802 (s), 748 (s); Raman (1064 nm, $\left.400 \mathrm{~mW}, 25^{\circ} \mathrm{C}, \mathrm{cm}^{-1}\right):=1606$ (13), 1588 (5), 1552 (11), 1500 (38), 1458 (5), 1441 (60), 1425 (7), 1386 (45), 1302 (13), 1057 (8), 1008 (9), 839 (25), 823 (3), 803 (5), 761 (5), 476 (7), 413 (10), 
351 (5), 327 (7), 227 (8), 90 (100); ${ }^{1} \mathrm{H}$ NMR ([D6]DMSO, ppm): $\delta=10.36$ (s, 1H, -NH); ${ }^{13} \mathrm{C}$ NMR ([D6]DMSO, ppm): $\delta=157.3\left(\mathrm{C}-\mathrm{NO}_{2}\right), 153.1\left(\mathrm{C}-\mathrm{NH}-\mathrm{NO}_{2}\right) ;{ }^{14} \mathrm{~N}$ NMR ([D6]DMSO, ppm): $\delta=-14.6$ $\left(\mathrm{N}-\mathrm{NO}_{2}\right),-28.9\left(\mathrm{C}-\mathrm{NO}_{2}\right) ; \mathrm{m} / z\left(\mathrm{FAB}^{-}\right): 174.0\left(\mathrm{C}_{2} \mathrm{~N}_{5} \mathrm{O}_{5}{ }^{-}\right), \mathrm{m} / z\left(\mathrm{DEI}^{+}\right): 175.0\left(\mathrm{C}_{2} \mathrm{HN}_{5} \mathrm{O}_{5}\right) ; \mathrm{EA}\left(\mathrm{C}_{2} \mathrm{HN}_{5} \mathrm{O}_{5}\right.$, 175.06): C 13.72, H 0.58, N 40.01, found: C 14.05, H 1.26, N 38.90; BAM impact: 4 J; BAM friction: $120 \mathrm{~N}$; ESD: $0.3 \mathrm{~J}$.

\subsection{Hydroxylammonium 3-nitramino-4-nitrofurazan (5)}

Compound 5 was synthesized as described in the literature [5].

DTA $\left(5^{\circ} \mathrm{C} \cdot \mathrm{min}^{-1}\right)$ onset: $149{ }^{\circ} \mathrm{C}$ (dec.), literature: $132{ }^{\circ} \mathrm{C}\left(\mathrm{m}\right.$.), $162.9{ }^{\circ} \mathrm{C}\left(\mathrm{dec}\right.$.) [5]; IR (ATR, $\left.\mathrm{cm}^{-1}\right)$ : $v=3070(\mathrm{~m}), 2866(\mathrm{~m}), 2719(\mathrm{~m}), 2400(\mathrm{w}), 1623(\mathrm{w}), 1577(\mathrm{~s}), 1506(\mathrm{~s}), 1451(\mathrm{~m}), 1410(\mathrm{~m}), 1380(\mathrm{~s})$, 1285 (vs), 1203 (vs), 1175 (s), 1047 (m), 1023 (s), 1007 (s), 943 (m), 848 (m), 808 (s), 771 (s), 748 (m), 704 (m); Raman (1064 nm, $\left.400 \mathrm{~mW}, 25^{\circ} \mathrm{C}, \mathrm{cm}^{-1}\right): v=3071$ (4), 2989 (4), 1625 (4), 1583 (10), 1535 (19), 1468 (10), 1453 (100), 1440 (24), 1427 (8), 1413 (20), 1385 (12), 1358 (20), 1339 (24), 1206 (10), 1181 (6), 1051 (14), 1026 (56), 1010 (15), 892 (6), 851 (20), 815 (6), 770 (7), 496 (11), 417 (10), 391 (8), 335 (16), 253 (10), 225 (11), 166 (29), 136 (21), 92 (64), 77 (36), 65 (37). ${ }^{1} \mathrm{H}$ NMR ([D6]DMSO, ppm): $\delta=10.06$ $\left(\mathrm{s}, 3 H, \mathrm{NH}_{3}-\mathrm{OH}^{+}\right), 9.87\left(\mathrm{~s}, 1 H, \mathrm{NH}_{3}-\mathrm{OH}^{+}\right) ;{ }^{13} \mathrm{C} \mathrm{NMR}([\mathrm{D} 6] \mathrm{DMSO}, \mathrm{ppm}): \delta=157.0\left(\mathrm{C}-\mathrm{NO}_{2}\right), 153.5$ $\left(\mathrm{C}-\mathrm{N}-\mathrm{NO}_{2}\right) ; m / z\left(\mathrm{FAB}^{-}\right): 174.1\left(\mathrm{C}_{2} \mathrm{~N}_{5} \mathrm{O}_{5}{ }^{-}\right), m / z\left(\mathrm{FAB}^{+}\right): 34.0\left(\mathrm{NH}_{4} \mathrm{O}^{+}\right) ; \mathrm{EA}\left(\mathrm{C}_{2} \mathrm{H}_{6} \mathrm{~N}_{6} \mathrm{O}_{4}, 178.11\right)$ : C 11.54, H 1.94, N 40.39, found: C 12.00, H 1.98, N 40.04; BAM impact: 10 J; BAM friction: 72 N; ESD: $0.5 \mathrm{~J}$.

\subsection{Ammonium 3-nitramino-4-nitrofurazan (6)}

Compound 6 was synthesized with a similar method as described in the literature [5].

DTA $\left(5^{\circ} \mathrm{C} \cdot \mathrm{min}^{-1}\right)$ onset: $97{ }^{\circ} \mathrm{C}$ (dec.), literature: $121{ }^{\circ} \mathrm{C}\left(\mathrm{dec}\right.$ ) $[5]$; IR (ATR, $\left.\mathrm{cm}^{-1}\right): v=3324(\mathrm{w})$, 3062 (w), 1579 (m), 1544 (w), 1464 (m), 1412 (s), 1370 (m), 1341 (s), 1278 (vs), 1205 (m), 1043 (m), $933(\mathrm{~m}), 830(\mathrm{~m}), 799(\mathrm{~s}), 778(\mathrm{~m}), 768(\mathrm{~m})$; Raman (1064 nm, $\left.400 \mathrm{~mW}, 25^{\circ} \mathrm{C}, \mathrm{cm}^{-1}\right): v=3139(2)$, 1572 (12), 1531 (16), 1465 (100), 1413 (22), 1366 (20), 1347 (26), 1296(7), 1206(7), 1045(19), 1010 (51), 934 (4), 830 (19), 802 (7), 741 (4), 496 (8), 422 (7), 386 (5), 334 (14), 249 (10), 218 (14), 162 (24), 128 (38), 105 (80), 84 (69); ${ }^{1} \mathrm{H}$ NMR ([D6]DMSO, ppm): $\delta=7.08$ (s, $\left.\mathrm{NH}_{4}{ }^{+}\right) ;{ }^{13} \mathrm{C}$ NMR ([D6]DMSO, ppm): $\delta=157.3\left(\mathrm{C}-\mathrm{NO}_{2}\right), 153.6\left(\mathrm{C}-\mathrm{N}-\mathrm{NO}_{2}\right) ; m / z\left(\mathrm{FAB}^{-}\right): 174.0\left(\mathrm{C}_{2} \mathrm{~N}_{5} \mathrm{O}_{5}{ }^{-}\right), m / z\left(\mathrm{FAB}^{+}\right): 18.1\left(\mathrm{NH}_{4}^{+}\right)$; EA $\left(\mathrm{C}_{2} \mathrm{H}_{6} \mathrm{~N}_{6} \mathrm{O}_{3}, 162.11\right)$ : C 12.51, H 2.10, N 43.75, found: C 12.91, H 2.14, N 43.48; BAM impact: $7 \mathrm{~J}$; BAM friction: $72 \mathrm{~N}$; ESD: $0.8 \mathrm{~J}$.

\subsection{4,4',5,5'-Tetraamino-3,3'-bi-triazolium di-3-nitramino-4-nitrofurazan (7)}

Freshly prepared $4(350 \mathrm{mg}, 2.0 \mathrm{mmol})$ and 4,4',5,5'-tetraamino-3,3'-bi-triazole [3] (196 mg, $1.0 \mathrm{mmol})$ were dissolved in approximately $400 \mathrm{~mL}$ of water, while the water was not warmed above $30{ }^{\circ} \mathrm{C}$. The solution was left in an open beaker to slowly evaporate the water to yield $470 \mathrm{mg}(0.86 \mathrm{mmol}, 86 \%)$ of 7 .

DTA $\left(5^{\circ} \mathrm{C} \cdot \mathrm{min}^{-1}\right)$ onset: $176{ }^{\circ} \mathrm{C}(\mathrm{dec}$ ) $)$ IR $\left(\mathrm{ATR}, \mathrm{cm}^{-1}\right): v=3460(\mathrm{w}), 3347(\mathrm{w}), 3245(\mathrm{~m}), 3187(\mathrm{~m})$, 1703 (s), 1623 (w), 1572 (s), 1525 (m), 1451 (m), 1419 (s), 1389 (m), 1358 (m), 1335 (m), 1280 (vs), $1199(\mathrm{~m}), 1093$ (w), 1045 (w), 999 (s), 972 (m), 940 (m), 828 (m), 800 (m), 776 (m); Raman (1064 nm, $\left.300 \mathrm{~mW}, 25^{\circ} \mathrm{C}, \mathrm{cm}^{-1}\right): v=3268$ (2), 1665 (6), 1650 (100), 1634 (12), 1616 (16), 1584 (8), 1527 (12), 
1452 (72), 1419 (10), 1392 (11), 1361 (16), 1335 (58), 1303 (14), 1047 (10), 1017 (36), 831 (13), 803 (21), 721 (7), 721 (7), 415 (7), 379 (4), 337 (15), 247 (4), 217 (5), 111 (50). ${ }^{1} \mathrm{H}$ NMR ([D6]DMSO, ppm): $\delta=8.55\left(\mathrm{~s}, 4 H,-\mathrm{NH}_{2}\right), 5.50\left(\mathrm{~s}, 4 H,-\mathrm{NH}_{2}\right) ;{ }^{13} \mathrm{C}$ NMR ([D6]DMSO, ppm): $\delta=157.2\left(\mathrm{C}-\mathrm{NO}_{2}\right), 153.5$ $\left(\mathrm{C}-\mathrm{N}-\mathrm{NO}_{2}\right), 152.0\left(\mathrm{C}-\mathrm{NH}_{2}\right), 137.7(\mathrm{C}-\mathrm{C}) ;{ }^{14} \mathrm{~N}$ NMR ([D6]DMSO, ppm): $\delta=-12.1\left(\mathrm{~N}-\mathrm{NO}_{2}\right)$, $-27.4 \mathrm{ppm}\left(\mathrm{C}-\mathrm{NO}_{2}\right) ; \mathrm{m} / z\left(\mathrm{ESI}^{-}\right): 174.0\left(\mathrm{C}_{2} \mathrm{~N}_{5} \mathrm{O}_{5}{ }^{-}\right), \mathrm{m} / z\left(\mathrm{ESI}^{+}\right): 197.1\left(\mathrm{C}_{4} \mathrm{H}_{9} \mathrm{~N}_{10}{ }^{+}\right) ; \mathrm{EA}\left(\mathrm{C}_{8} \mathrm{H}_{10} \mathrm{~N}_{20} \mathrm{O}_{10}\right.$, 546.09): C 17.59, H 1.85, N 51.28; found: C 17.87, H 1.87, N 51.11; BAM impact: 3 J; BAM friction: $252 \mathrm{~N}$; ESD: $0.75 \mathrm{~J}$.

\subsection{3,6,7-Triamino-[1,2,4]triazolo[4,3-b][1,2,4]triazolium 3-nitramino-4-nitrofurazan (8)}

Freshly prepared 4 (280 mg, $1.6 \mathrm{mmol})$ and 3,6,7-triamino-[1,2,4]triazolo[4,3-b][1,2,4]triazole [4] (246 mg, $1.6 \mathrm{mmol}$ ) were dissolved in $100 \mathrm{~mL}$ of water, while the water was not warmed above $30{ }^{\circ} \mathrm{C}$. The solution was left for crystallization to yield $350 \mathrm{mg}(1.06 \mathrm{mmol}, 66 \%)$ of $\mathbf{8}$ as colorless crystals.

DTA $\left(5^{\circ} \mathrm{C} \cdot \mathrm{min}^{-1}\right)$ onset: $193{ }^{\circ} \mathrm{C}\left(\mathrm{dec}\right.$ )); IR (ATR, $\left.\mathrm{cm}^{-1}\right): v=3422(\mathrm{~m}), 3364(\mathrm{w}), 3293(\mathrm{~m}), 3239(\mathrm{~m})$, 3175 (m), 3134 (m), 1706 (s), 1674 (s), 1648 (s), 1579 (s), 1540 (m), 1458 (m), 1414 (m), 1368 (vs), 1298 (vs), 1207 (m), 1049 (m), 1035 (m), 1016 (m), 976 (w), 845 (m), 822 (s), 776 (m), 740 (m), 722 (m), $704(\mathrm{~m}), 695$ (m), $666(\mathrm{w})$; Raman (1064 nm, $\left.300 \mathrm{~mW}, 25^{\circ} \mathrm{C}, \mathrm{cm}^{-1}\right): v=3244$ (7), 1699 (8), 1673 (7), 1575 (10), 1543 (16), 1462 (73), 1427 (12), 1373 (15), 1306 (15), 1263 (23), 1209 (15), 1053 (32), 1019 (10), 849 (31), 825 (17), 765 (7), 681 (7), 619 (22), 602 (18), 502 (22), 390 (21), 303 (18), 244 (8), 244 (8), 217 (12), 137 (100), 99 (54), 85 (43); ${ }^{1} \mathrm{H}$ NMR ([D6]DMSO, ppm): $\delta=13.14$ (br, s, $1 \mathrm{H}, \mathrm{N}-\mathrm{H}$ ), $8.16\left(\mathrm{~s}, 2 \mathrm{H},-\mathrm{NH}_{2}\right), 7.21\left(\mathrm{~s}, 2 \mathrm{H},-\mathrm{NH}_{2}\right), 5.76\left(\mathrm{~s}, 2 \mathrm{H},-\mathrm{NH}_{2}\right) ;{ }^{13} \mathrm{C}$ NMR ([D6]DMSO, ppm): $\delta=160.2\left(\mathrm{C}-\mathrm{NH}_{2}\right), 157.2\left(\mathrm{C}-\mathrm{N}-\mathrm{NO}_{2}\right), 153.5\left(\mathrm{C}-\mathrm{NO}_{2}\right), 147.5\left(\mathrm{C}_{\mathrm{q}}\right), 141.2\left(\mathrm{C}-\mathrm{NH}_{2}\right) ;{ }^{14} \mathrm{~N}$ NMR ([D6]DMSO, ppm): $\delta=-12.1\left(\mathrm{~N}-\mathrm{NO}_{2}\right),-27.5 \mathrm{ppm}\left(\mathrm{C}-\mathrm{NO}_{2}\right) ; \mathrm{m} / z\left(\mathrm{FAB}^{-}\right): 174.1\left(\mathrm{C}_{2} \mathrm{~N}_{5} \mathrm{O}_{5}{ }^{-}\right)$, $m / z\left(\mathrm{FAB}^{+}\right): 155.2\left(\mathrm{C}_{3} \mathrm{H}_{7} \mathrm{~N}_{8}{ }^{+}\right)$; $\mathrm{EA}\left(\mathrm{C}_{5} \mathrm{H}_{7} \mathrm{~N}_{13} \mathrm{O}_{5}, 329.07\right)$ : C 18.24, H 2.14, N 55.31; found: $\mathrm{C} 18.42$, H 2.21, N 55.32; BAM impact: 6 J; BAM friction: 324 N; ESD: 1.2 J.

\subsection{4,4',5,5'-Tetraamino-3,3'-bi-triazolium dinitraminoazoxyfurazan (11)}

4,4',5,5'-Tetraamino-3,3'-bi-triazole [3] (0.78 g, $4.00 \mathrm{mmol}, 2.0$ equiv.) was suspended in 4.0 L of hot water. Compound $10(0.64 \mathrm{~g}, 2.00 \mathrm{mmol})$ was added and the suspension was heated until a clear solution was formed. The solution was filtered and the solvent was evaporated in air. 11 precipitated as an orange powder. Yield: $1.17 \mathrm{~g}, 1.7 \mathrm{mmol}, 85 \%$.

DTA $\left(5^{\circ} \mathrm{C} \cdot \mathrm{min}^{-1}\right)$ onset: $212^{\circ} \mathrm{C}\left(\mathrm{dec}\right.$ )) IR (ATR, $\left.\mathrm{cm}^{-1}\right): v=3604(\mathrm{w}), 3528(\mathrm{w}), 3357(\mathrm{w}), 3202(\mathrm{w})$, 3052 (w), 1698 (s), 1610 (m), 1555 (m), 1524 (m), 1445 (m), 1426 (s), 1389 (s), 1262 (br, vs), 1172 (m), 1123 (w), 1017 (m), 985 (s), 936 (s), 817 (m), 784 (m), 753 (m), 707 (m); Raman (1064 nm, 300 mW, $\left.25^{\circ} \mathrm{C}, \mathrm{cm}^{-1}\right): v=1655$ (81), 1632 (13), 1556 (8), 1526 (19), 1475 (97), 1459 (31), 1436 (97), 1390 (32), 1335 (41), 1315 (100), 1296 (18), 1271 (12), 1083 (6), 1042 (10), 1020 (28), 1006 (16), 956 (7), 862 (13), 820 (9), 803 (24), 754 (5), 712 (7), 497 (9), 478 (8), 399 (6), 263 (6), 231 (10), 129 (23); ${ }^{1} \mathrm{H}$ NMR ([D6]DMSO, ppm]): $\delta=8.53\left(\mathrm{~s}, 4 \mathrm{H},-\mathrm{NH}_{2}\right), 6.12\left(\mathrm{~s}, 4 \mathrm{H},-\mathrm{NH}_{2}\right) ;{ }^{13} \mathrm{C}$ NMR ([D6]DMSO, ppm): $\delta=155.1(\mathrm{C}-\mathrm{N}(\mathrm{O})-\mathrm{N}), 153.9(\mathrm{C}-\mathrm{N}-\mathrm{N}(\mathrm{O})), 152.0\left(\mathrm{C}-\mathrm{NH}_{2}\right.$ cat. $), 151.2\left(\mathrm{C}-\mathrm{N}-\mathrm{NO}_{2}\right), 137.8(\mathrm{C}-\mathrm{C}$ cat. $)$; ${ }^{14} \mathrm{~N} \quad \mathrm{NMR} \quad([\mathrm{D} 6] \mathrm{DMSO}, \quad \mathrm{ppm}): \quad \delta=-13.4 \quad\left(\mathrm{~N}-\mathrm{NO}_{2}\right), \quad-66.8 \quad(\mathrm{~N}-\mathrm{N}(\mathrm{O})) ; \quad m / z \quad\left(\mathrm{FAB}^{-}\right)$: $285.0\left(\mathrm{C}_{4} \mathrm{H}_{13} \mathrm{~N}_{16} \mathrm{O}_{4}{ }^{-}\right)$; EA $\left(\mathrm{C}_{8} \mathrm{H}_{10} \mathrm{~N}_{20} \mathrm{O}_{7} \cdot \mathrm{H}_{2} \mathrm{O}, 516.31\right)$ : C 18.61, H 2.34, N 54.26; found: C 18.82, H 2.85, N 53.64; BAM impact: 20 J; BAM friction: $240 \mathrm{~N}$; ESD: $0.25 \mathrm{~J}$. 


\subsection{Di-3,6,7-triamino-[1,2,4]triazolo[4,3-b][1,2,4]triazolium dinitraminoazoxyfurazan (12)}

3,6,7-triamino-[1,2,4]triazolo[4,3-b][1,2,4]triazole [4] $(0.61 \mathrm{~g}, 4.0 \mathrm{mmol})$ was suspended in $300 \mathrm{~mL}$ of hot water. Compound $\mathbf{1 0}(0.64 \mathrm{~g}, 2.00 \mathrm{mmol})$ was added and the suspension was heated until a clear solution was formed. The solution was filtered and the solvent was evaporated in air. $\mathbf{1 2}$ precipitated as colorless crystals( $1.03 \mathrm{~g}, 3.3 \mathrm{mmol}, 82 \%)$.

DTA $\left(5^{\circ} \mathrm{Cmin}^{-1}\right)$ onset: $266^{\circ} \mathrm{C}\left(\mathrm{dec}\right.$.); IR $\left(\mathrm{ATR}, \mathrm{cm}^{-1}\right): v=3436(\mathrm{w}), 3384(\mathrm{~m}), 3226(\mathrm{~m}), 3116(\mathrm{~m})$, 2757 (w), 1690 (vs), 1652 (vs), 1566 (m), 1496 (s), 1477 (m), 1400 (s), 1365 (s), 1319 (s), 1286 (vs), 1188 (m), 1138 (m), 1060 (m), 1038 (m), 1012 (m), 981 (m), 931 (m), 879 (w), $846(\mathrm{~m}), 810$ (m), $770(\mathrm{~m})$, 733 (w), 707 (m); Raman (1064 nm, $\left.300 \mathrm{~mW}, 25^{\circ} \mathrm{C}, \mathrm{cm}^{-1}\right): v=1649$ (11), 1568 (11), 1539 (19), 1497 (25), 1480 (39), 1445 (77), 1420 (18), 1348 (12), 1326 (13), 1257 (19), 1193 (18), 1049 (40), 879 (9), 851 (23), 757 (14), 620 (21), 598 (15), 491 (18), 413 (8), 394 (10), 328 (13), 309 (17), 228 (12), 187 (23), 129 (77), 101 (100), 76 (33); ${ }^{1} \mathrm{H}$ NMR ([D6]DMSO, ppm): $\delta=13.29(\mathrm{~s}, 2 \mathrm{H}, \mathrm{N}-\mathrm{H}), 8.19\left(\mathrm{~s}, 4 \mathrm{H},-\mathrm{NH}_{2}\right)$, $7.22\left(\mathrm{~s}, 4 \mathrm{H},-\mathrm{NH}_{2}\right), 5.77\left(\mathrm{~s}, 4 \mathrm{H},-\mathrm{NH}_{2}\right) ;{ }^{13} \mathrm{C} \mathrm{NMR}$ ([D6]DMSO, ppm): $\delta=160.1\left(\mathrm{C}-\mathrm{NH}_{2}, \mathrm{ppm}\right)$, $155.0(\mathrm{C}-\mathrm{N}(\mathrm{O})-\mathrm{N}), 153.9(\mathrm{C}-\mathrm{N}-\mathrm{N}(\mathrm{O})), 151.2\left(\mathrm{C}-\mathrm{N}-\mathrm{NO}_{2}\right), 147.4\left(\mathrm{C}_{\mathrm{q}}\right), 141.1\left(\mathrm{C}-\mathrm{NH}_{2}\right) ;{ }^{14} \mathrm{~N}$ NMR ([D6]DMSO, ppm): $\delta=-12.7\left(\mathrm{~N}-\mathrm{NO}_{2}\right),-66.1(\mathrm{~N}-\mathrm{N}(\mathrm{O})) ; \mathrm{m} / z\left(\mathrm{FAB}^{-}\right): 285.0\left(\mathrm{C}_{4} \mathrm{H}_{13} \mathrm{~N}_{16} \mathrm{O}_{4}^{-}\right)$; EA $\left(\mathrm{C}_{10} \mathrm{H}_{14} \mathrm{~N}_{26} \mathrm{O}_{7}, 610.40\right)$ : C 19.68, H 2.31, N 59.66; found: C 19.74, H 2.45, N 59.66; BAM impact: $10 \mathrm{~J}$; BAM friction: $360 \mathrm{~N}$; ESD: $0.5 \mathrm{~J}$.

\section{Conclusions}

Energetic derivatives of 3-nitramino-4-nitrofurazan and dinitraminoazoxyfurazan were investigated in the search for more thermally stable materials. The crystal structures were determined by low temperature single crystal X-ray diffraction and show the stabilizing effect of a strong hydrogen-bonding network formed by the 3,6,7-triamino-[1,2,4]triazolo[4,3-b][1,2,4]triazolium cation. Moreover, the X-ray structures of highly dense hydroxylammonium and ammonium 3-nitramino-4nitrofurazan were reported. Even though neutral $\mathbf{4}$ and salt 5 have excellent detonation parameters (D $9500 \mathrm{~m} \cdot \mathrm{s}^{-1}, p_{\mathrm{CJ}} 400 \mathrm{kbar}$ ), their application is unlikely because of their low thermal stability. To our dismay, thermally more stable salts $\mathbf{7}$ and $\mathbf{8}$ fell short of a decomposition temperature of $200{ }^{\circ} \mathrm{C}$. However the dinitraminoazoxyfurazan 12 shows a high thermal stability due to an extensive hydrogen bonding network, with sufficient stability against impact and friction, and yet a detonation velocity D $9000 \mathrm{~m} \cdot \mathrm{s}^{-1}$, which is similar to RDX.

\section{Acknowledgments}

Financial support of this work by the Ludwig-Maximilian University of Munich (LMU), the U.S. Army Research Laboratory (ARL), the Armament Research, Development and Engineering Center (ARDEC) the Office of Naval Research (ONR) under grant no. ONR.N00014-12-1-0538, and the Bundeswehr-Wehrtechnische Dienststelle für Waffen und Munition (WTD 91) under grant no. E/E91S/FC015/CF049 is gratefully acknowledged. The authors acknowledge collaborations with Mila Krupka (OZM Research, Czech Republic) in the development of new testing and evaluation methods for energetic materials and with Muhamed Suceska (Brodarski Institute, Croatia) in the development of new computational codes to predict the detonation and propulsion parameters of novel 
explosives. We are indebted to and thank Betsy M. Rice, Jesse Sabatini and Brad Forch (ARL, Aberdeen, Proving Ground, MD) for many inspired discussions. The authors want to thank Stefan Huber for assistance with the measurement of the sensitivities as well as Marcel Leroux, Fang Wang and Austin Clark for their contributions to this paper.

\section{Author Contributions}

P.S. and J.S. conceived and designed the experiments; T.K. contributed reagents/materials/analysis tools; J.S. performed the X-ray diffraction experiments; P.S. wrote the paper.

\section{Conflicts of Interest}

The authors declare no conflict of interest

\section{References}

1. Giles, J. Green explosives: Collateral damage. Nature 2004, 427, 580-581.

2. Gao, H.; Shreeve, J.M. Azole based energetic salts. Chem. Rev. 2011, 11, 7377-7436.

3. Klapötke, T.M.; Schmid, P.C.; Schnell, S.; Stierstorfer, J. Thermal stabilization of energetic materials by the aromatic nitrogen-rich 4,4',5,5'-tetraamino-3,3'-bi-1,2,4-triazolium cation. $J$. Mat Chem. A. 2015, 3, 2658-2668.

4. Klapötke, T.M.; Schmid, P.C.; Schnell, S.; Stierstorfer, J. 3,6,7-Triamino-[1,2,4]triazolo [4,3-b][1,2,4]triazole: A non-toxic, high-performance energetic building block with excellent stability. Chem Eur. J. 2015, 21, doi:10.1002/chem.201500982.

5. Willer, R.L.; Day, R.S.; Park, D.J. Liquid gun propellants. U.S. Patent 5,460,669, 24 October 1995.

6. Fischer, D.; Klapötke, T.M.; Reymann, M.; Stierstorfer, J. Dense energetic nitraminofurazanes. Chem. Eur. J. 2014, 20, 6401-6411.

7. Willer, R. Calculation of the density and detonation properties of C, H, N, O and F compounds: Use in the design and synthesis of new energetic materials. J. Mex. Chem. Soc. 2009, 53, 108-119.

8. Glyoxime, Diaminofurazan and some Energetic Derivatives, by AXT. Available online: http:// www.sciencemadness.org/member_publications/energetic_glyoxime_and_diaminofurazan_derivat ives.pdf (accessed on 31 July 2015).

9. Novikova, T.S.; Mel'nikova, T.M.; Kharitonova, O.V.; Kulagina, V.O.; Aleksandrova, N.S.; Sheremetev, A.B.; Pivina, T.S.; Khmel'nitskii, L.I.; Novikov, S.S. An effective method for the oxidation of aminofurazans to nitrofurazans. Mendeleev Commun. 1994, 4, 138-140.

10. Beal, R.W. Structures and chemistry of amino and nitro furazanes. Master's Thesis, University of Delaware, Newark, DE, USA, 2000.

11. Francois, E.G.; Chavez, D.E.; Sandstrom, M.M. The development of a new synthesis process for 3,3'-Diamino-4,4'-azoxyfurazan (DAAF). Propellants Explos. Pyrotech. 2010, 35, 529-534.

12. Batsanov, A.S.; Struchkov, Y.T. Crystal structure of 3,4-diaminofurazan and 3-aminon-4nitrofurazan. J. Struct. Chem. 1985, 26, 52-56. 
13. Klapötke, T.M.; Leroux, M.; Schmid, P.C.; Schnell, S.; Stierstorfer, J. Energetic materials based on 5,5'-diamino-4,4'-dinitramino-3,3'-bi(1,2,4-triazole). Chem. Asian J. 2015, doi: 10.1002/ asia.201500701.

14. Murray, S.; Politzer, P. Chemistry and Physics of Energetic Materials; Bulusu, S.N., Ed.; Kluwer: Dordrecht, The Netherlands, 1990; pp. 157-173.

15. Murray, J.S.; Politzer, P. Impact sensitivity and crystal lattice compressibility/free space. J. Mol. Model 2014, 20, 2223-2227.

16. Xue, C.; Sun, J.; Kang, B.; Liu, Y.; Liu, X.; Song, G.; Xue, Q. The $\beta$ - $\delta$-phase transition and thermal expansion of octahydro-1,3,5,7-tetranitro-1,3,5,7-tetrazocine. Propellants Explos. Pyrotech. 2010, 35, 333-338.

17. EXPLO5V6.02 program; Brodarski Institute: Zagreb, Croatia, 2014.

(C) 2015 by the authors; licensee MDPI, Basel, Switzerland. This article is an open access article distributed under the terms and conditions of the Creative Commons Attribution license (http://creativecommons.org/licenses/by/4.0/). 